\title{
Finansowanie przedsiębiorstw społecznych w Polsce
}

\author{
Tomasz Schimanek*
}

\begin{abstract}
Streszczenie: $\quad$ W artykule pokazano, w jaki sposób definiowane jest przedsiębiorstwo społeczne w Polsce i jakie podmioty mogą spełniać tę definicję. Wskazano, jakie są główne źródła finansowania przedsiębiorstw społecznych, a na podstawie dostępnych, fragmentarycznych badań omówiono praktyczne ich wykorzystanie i kondycję finansową przedsiębiorstw społecznych. Kondycja ta nie jest najlepsza, a dominującym źródłem finansowania większości przedsiębiorstw społecznych są środki publiczne. W oparciu o wyniki przeprowadzonych badań sformułowano ogólne konkluzje i wyzwania dotyczące finansowania przedsiębiorstw społecznych w Polsce. Najważniejszą jest skuteczne wykorzystanie Krajowego Programu Rozwoju Ekonomii Społecznej do wzmocnienia kondycji finansowej przedsiębiorstw społecznych i budowania ich niezależności od środków publicznych.
\end{abstract}

Słowa kluczowe: przedsiębiorczość społeczna, przedsiębiorstwo społeczne, finansowanie, Krajowy Program Rozwoju Ekonomii Społecznej.

\section{Wprowadzenie}

Przedsiębiorczość społeczna w Polsce ma długą tradycję, przerwaną po II Wojnie Światowej. Ruch spółdzielczy, który był fundamentem ówczesnej przedsiębiorczości społecznej, został w okresie PRL-u upaństwowiony, co spowodowało utratę wielu jego charakterystycznych cech, przede wszystkim niezależności i autonomii działania [Sienicka, 2009, s. 8]. Odrodzenie przedsiębiorczości społecznej w Polsce nastąpiło kilkanaście lat temu, głównie za sprawą dwóch czynników. Jednym z nich była możliwość wsparcia działań w tym obszarze ze środków Europejskiego Funduszu Społecznego w ramach Inicjatywy Wspólnotowej EQUAL (2005-2008), drugą działania polskiego rządu, które zaowocowały m.in. uchwaleniem ustawy o zatrudnieniu socjalnym (2003) i ustawy o spółdzielniach socjalnych (2006), tworzących prawno-instytucjonalną formę dla rozwoju przedsiębiorczości społecznej [ibidem, s. 8].

Nowa przedsiębiorczość społeczna, w zależności od tradycji historycznej lub kontekstu naukowego nazywana także gospodarką społeczną, ekonomią solidarną a niekiedy ekonomią społeczną, jest obecna nie tylko w debacie publicznej czy dyskursie teoretycznym, ale - co istotne - w praktyce działań obywatelskich. Funkcjonują dotychczasowe i powstają nowe przedsiębiorstwa społeczne, rozwija się infrastruktura wsparcia, opracowywane są programy rządowe służące rozwojowi przedsiębiorczości społecznej. Mówi się o nowej fali ekonomii społecznej, która przetacza się nie tylko przez Polskę, ale także inne kraje europejskie [Herbst, 2013, s. 10-11], a której fundamentem jest właśnie przedsiębiorczość społeczna. Towarzyszą temu próby definiowania przedsiębiorczości społecznej oraz szerzej rozumianej ekonomii społecznej, podejmowane zarówno w Polsce, jak i zagranicą [Grewiński, 2012, s. 3-14]. Niezależnie od różnic definicyjnych, wspólną cechą przedsiębiorczości

\section{* Tomasz Schimanek}

Akademia Rozwoju Filantropii w Polsce ul. Marszałkowska 6/6, 00-590 Warszawa e-mail: tomeks@filantropia.org.pl 
społecznej jest łączenie tego, co społeczne z tym, co ekonomiczne [Kaźmierczak, 2007, s. 112]. Inaczej mówiąc przedsiębiorczość społeczna to wykorzystanie działalności komercyjnej dla celów społecznych. W taki też sposób określiła przedsiębiorczość społeczną Komisja Europejska, opisując ją jako działalność dążącą do realizacji celów społecznych za pomocą narzędzi biznesowych [Proposal..., 2011, s. 18]. Realizacji celów społecznych służą trzy podstawowe mechanizmy. Pierwszy to integracja zawodowa i społeczna osób w trudnej sytuacji życiowej poprzez zatrudnienie ich $w$ ramach prowadzonej działalności gospodarczej oraz objęcie wsparciem psychologicznym, doradczym i szkoleniowym. Drugi to świadczenie w ramach działalności gospodarczej usług, które zaspokajają istotne społecznie potrzeby, np. usług edukacyjnych, socjalnych, opiekuńczych. Trzeci mechanizm to przeznaczanie zysków z działalności gospodarczej na cele społecznie użyteczne, np. na rehabilitację zatrudnionych osób niepełnosprawnych czy też stypendia dla dzieci z ubogich rodzin [Schimanek, 2011, s. 2]. W praktyce te mechanizmy realizują przedsiębiorstwa społeczne, którą są podstawowym, ale nie jedynym, podmiotem działającym w sferze ekonomii społecznej. Siła i zakres oddziaływania przedsiębiorstw społecznych zależy w dużej mierze od możliwości pozyskiwania przez nie środków na działalność i ich kondycji finansowej. Niniejszy artykuł jest próbą przyjrzenia się finansowaniu działalności przedsiębiorstw społecznych w Polsce i wskazania głównych wyzwań z tym związanych.

\section{Definicja przedsiębiorczości społecznej i przedsiębiorstwa społecznego}

Aby przyjrzeć się finansowaniu przedsiębiorstw społecznych, trzeba na początku ustalić, czym jest przedsiębiorstwo społeczne ijakie podmioty obejmuje to określenie.W Pol- sce od ponad dziesięciu lat trwają próby zdefiniowania pojęć związanych z przedsiębiorczością społeczną, w tym także określenia pojęcia przedsiębiorstwa społecznego. Dotyczą one zarówno kontekstu teoretycznego, jak i praktycznego. Wielość podejść i definicji oddają dotychczasowe opracowania [Frączek, Hausner, Mazur, 2012; Hausner, 2008]. Podobnie zresztą ma się rzecz w Europie i na świecie [Lech, 2012]. Równolegle podejmowane są również wysiłki zdefiniowania podstawowych pojęć związanych z przedsiębiorczością społeczną na gruncie prawa, dotychczas jednak zakończone niepowodzeniem. Brak ustawowych regulacji sfery przedsiębiorczości społecznej pogłębia chaos w sferze pojęciowej [Schimanek, 2013, s. 10]. Aby go uporządkować, rząd zdecydował się określić definicje ekonomii społecznej i przedsiębiorstwa społecznego w Krajowym Programie Rozwoju Ekonomii Społecznej, który został przyjęty w 2014 r. w drodze uchwały Rady Ministrów [Krajowy Program..., 2014]. Nie jest to, co prawda, źródło powszechnie obowiązującego prawa, ale na razie jest to jedyny akt prawny, w którym przyjęte zostały definicje ekonomii społecznej i przedsiębiorstwa społecznego. Jako uchwała Rady Ministrów obowiązuje on administrację rządową, a praktyka pokazuje, że definicje zawarte w Programie stosowane są również przez samorządy terytorialne. Jest to, jak dotychczas, jedyna, oficjalna i powszechna definicja przedsiębiorstwa społecznego, stąd też przyjęto ją na użytek dalszych rozważań.

Zgodnie z Krajowym Programem Rozwoju Ekonomii Społecznej (KPRES) ekonomia społeczna to sfera aktywności obywatelskiej, która poprzez działalność ekonomiczną i działalność pożytku publicznego służy: integracji zawodowej i społecznej osób zagrożonych marginalizacją społeczną, tworzeniu miejsc pracy, świadczeniu usług społecznych użyteczności publicznej (na rzecz interesu ogólnego) oraz rozwojowi lokalnemu. W tej sferze działają 
cztery podstawowe i piąta dodatkowa grupy podmiotów:

- przedsiębiorstwa społeczne, będące fundamentem ekonomii społecznej,

- podmioty reintegracyjne, służące reintegracji społecznej i zawodowej osób zagrożonych wykluczeniem społecznym, tj. Zakłady Aktywności Zawodowej, Warsztaty Terapii Zajęciowej, Centra Integracji Społecznej, Kluby Integracji Społecznej; podmioty te nie są przedsiębiorstwami społecznymi, ale mogą przygotowywać do prowadzenia lub pracy w przedsiębiorstwie społecznym lub być prowadzone jako usługa na rzecz społeczności lokalnej przez przedsiębiorstwa społeczne,

- podmioty działające w sferze pożytku publicznego, które prowadzą działalność ekonomiczną i zatrudniają pracowników, choć ich aktywność nie jest oparta na ryzyku ekonomicznym; są to organizacje pozarządowe prowadzące działalność odpłatną i nieodpłatną pożytku publicznego,

- podmioty sfery gospodarczej, które tworzone były w związku z realizacją celu społecznego, bądź dla których leżący we wspólnym interesie cel społeczny jest racją bytu działalności komercyjnej; są to podmioty, które nie posiadają wszystkich cech przedsiębiorstwa społecznego. Należą do nich na przykład: organizacje pozarządowe prowadzące działalność gospodarczą, Zakłady Aktywności Zawodowej prowadzące działalność gospodarczą, spółdzielnie, których celem jest zatrudnienie oraz pozostałe spółdzielnie o charakterze konsumenckim i wzajemnościowym.

Piątą, dodatkową grupą podmiotów działających w sferze ekonomii społecznej są inicjatywy o charakterze nieformalnym. Należą do nich m.in. kooperatywy spożywców, inne przedsięwzięcia działające w sferze wzajemnościowej, różnorakie ruchy miejskie, lokatorskie i sąsiedzkie czy też ruch spółdzielni uczniowskich.
Autorzy KPRES przyjęli bardzo szeroką definicję ekonomii społecznej, pozwalającą zaliczyć do tej sfery różnorodne formy działań obywatelskich, także tych niesformalizowanych. Definicja ta określa trzy wyróżniki podmiotu działającego w sferze ekonomii społecznej:

- prowadzenie działalności ekonomicznej, która jak wynika z wymienionych wcześniej grup podmiotów, obejmuje zarówno działalność gospodarczą, jak i działalność odpłatną pożytku publicznego, oraz wzajemnościową wymianę dóbr i usług o charakterze nieformalnym,

- prowadzenie działalności pożytku publicznego; została ona określona w ustawie o działalności pożytku publicznego i o wolontariacie i obejmuje obecnie trzydzieści dziewięć, bardzo szeroko zdefiniowanych obszarów działania,

- określone cele działalności; to cecha najbardziej dookreślona ze wszystkich trzech, choć sformułowane w KPRES cele działań podmiotów ekonomii społecznej także są dość pojemne: integracja zawodowa i społeczna osób zagrożonych marginalizacją społeczną, tworzenie miejsc pracy, świadczenie usług społecznych użyteczności publicznej i rozwój lokalny.

Na uwagę zasługuje to, że autorzy KPRES jako fundament ekonomii społecznej określają przedsiębiorstwa społeczne, które są przedmiotem dalszych rozważań. W związku z tym KPRES definiuje również, czym jest przedsiębiorstwo społeczne. Spełnia ono przede wszystkim trzy wspomniane wyżej kryteria podmiotu ekonomii społecznej, a dodatkowo:

- prowadzi działalność gospodarczą wyodrębnioną pod względem organizacyjnym i rachunkowym,

- celem działalności gospodarczej jest integracja społeczna i zawodowa osób zagrożonych wykluczeniem społecznym (w tym przypadku wymagane jest zatrudnienie co najmniej 50\% osób pochodzących z grup zagrożonych wykluczeniem społecznym lub 30\% niepełnosprawnych o umiarko- 
wanym lub znacznym stopniu niepełnosprawności) lub świadczenie usług społecznych użyteczności publicznej, przy jednoczesnej realizacji celów prozatrudnieniowych (zatrudnienie min. 20\% osób z określonych grup zagrożonych wykluczeniem społecznym),

- nie rozdziela zysku lub nadwyżki bilansowej pomiędzy udziałowców, ale przeznacza go na wzmocnienie potencjału przedsiębiorstwa jako kapitał niepodzielny oraz w określonej części na reintegrację zawodową i społeczną (w przypadku przedsiębiorstw o charakterze zatrudnieniowym) lub na działalność pożytku publicznego prowadzoną na rzecz społeczności lokalnej, w której działa przedsiębiorstwo,

- jest zarządzane na zasadach demokratycznych lub co najmniej konsultacyjno-doradczych z udziałem pracowników i innych interesariuszy, zaś wynagrodzenia kadry zarządzającej są ograniczone limitami.

Powyższa definicja przedsiębiorstwa społecznego w dużej mierze nawiązuje do często wykorzystywanej w literaturze definicji przedsiębiorstwa społecznego EMES (European Research Network) [Defourny, Nyssens, 2012, s. 12-15]. Obejmuje ona zestaw kryteriów ekonomicznych, społecznych i dotyczących zarządzania wyróżniających przedsiębiorstwo społeczne.

Kryteria ekonomiczne to:

- prowadzenie w sposób ciągły, regularny działalności polegającej na produkcji dóbr lub wytwarzaniu usług,

- ponoszenie ryzyka gospodarczego,

- istnienie choćby nielicznego płatnego personelu.

Kryteria społeczne:

- wyraźna orientacja na społecznie użyteczny cel przedsięwzięcia,

- oddolny, obywatelski charakter inicjatywy,

- ograniczona dystrybucja zysków.

Kryteria dotyczące partycypacyjnego zarządzania:
- duży stopień niezależności działania,

- decydowanie nieoparte na własności kapitału,

- partycypacyjna natura, uwzględniająca udział w zarządzaniu różnych interesariuszy.

Definicja przedsiębiorstwa społecznego sformułowana w KPRES bardzo silnie eksponuje kwestię zatrudnienia osób zagrożonych wykluczeniem społecznym, co nie pojawia się w definicji EMES. Z kolei ta ostatnia podkreśla niezależność działania przedsiębiorstwa społecznego, co z kolei nie pojawia się w kryteriach określonych w KPRES. EMES dopuszcza również ograniczoną dystrybucję zysków pomiędzy udziałowców/członków, co wyklucza całkowicie KPRES. Kwestią oddzielnych rozważań jest dociekanie przyczyn tych różnic, warto jednak zwrócić uwagę na to, że przedsiębiorstwo społeczne opisane w KPRES jest bliższe sektorowi publicznemu i mniej „urynkowione" niż to określone przez EMES. Wydaje się to być wyrazem świadomego podejścia państwa do przedsiębiorczości społecznej, traktowanej przede wszystkim jako instrument integracji społeczno-zawodowej, co potwierdza umieszczenie w KPRES integracji jako jednego z dwóch dopuszczalnych celów działania przedsiębiorstwa społecznego. Warto zwrócić na to uwagę, gdyż wydaje się to nie bez znaczenia dla finansowania działalności przedsiębiorstw społecznych.

\section{Ogólna charakterystyka przedsiębiorstw społecznych}

Definicja przedsiębiorstwa społecznego sformułowana w Krajowym Programie Rozwoju Ekonomii Społecznej na razie nie została uwzględniona w sposób kompleksowy w żadnych badaniach, nie jest też stosowana w statystyce publicznej. Stąd też nie ma danych, które w sposób jednorodny i spójny opisywałyby określoną w KPRES populację przedsiębiorstw społecznych. Można pró- 


\section{Rysunek 1. Przedsiębiorstwa społeczne w Polsce}

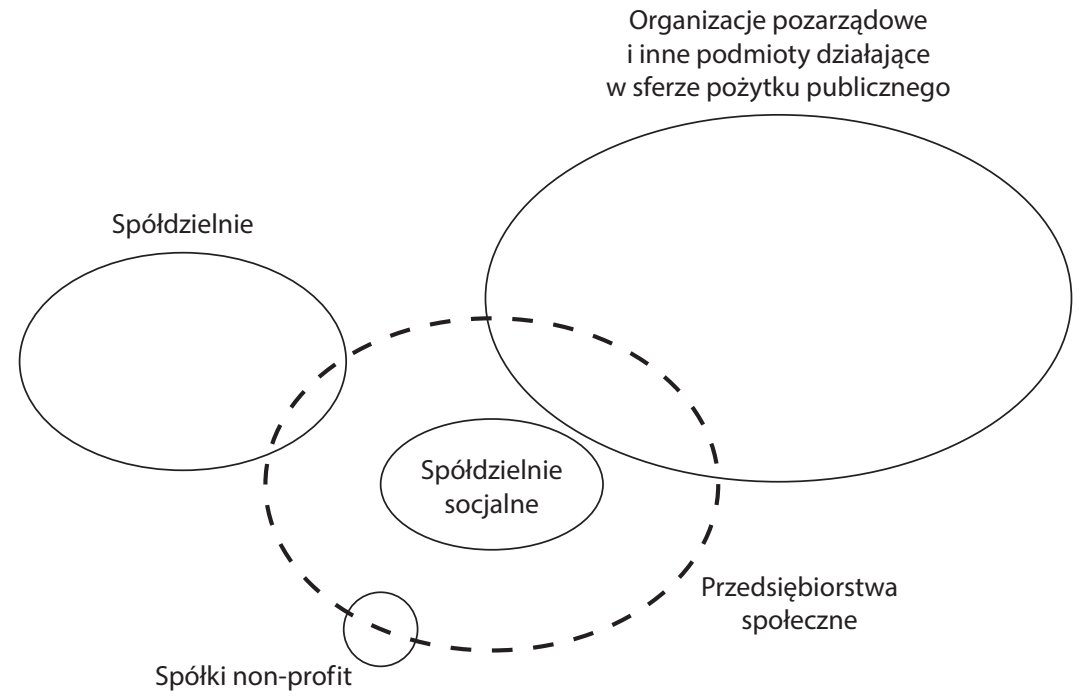

Źródło: opracowanie własne.

bować jedynie fragmentarycznie opisać ją poprzez dane dotyczące różnych grup podmiotów wchodzących w jej skład. Zgodnie z definicją określoną w KPRES przedsiębiorstwem społecznym jest każda spółdzielnia socjalna, gdyż zgodnie z ustawą o spółdzielniach socjalnych, musi spełniać wyżej opisane cechy. Po za tym przedsiębiorstwa społeczne mogą rekrutować się z:

- organizacji pozarządowych prowadzących działalność gospodarczą,

- innych podmiotów działających w sferze pożytku publicznego, prowadzących działalność gospodarczą, np. kościołów, organizacji kościelnych,

- podmiotów gospodarczych, które spełniają powyższe cechy, na przykład spółdzielni czy też tak zwanych spółek non-profit.

Grupą podmiotów w całości spełniających definicję przedsiębiorstwa społecznego są spółdzielnie socjalne. Dane Ministerstwa Pracy i Polityki Społecznej pokazują, że począwszy od 2009 r. zwiększa się liczba zarejestrowanych spółdzielni socjalnych [Informacja, 2015].
Nie ma natomiast wiarygodnych danych dotyczących liczby faktycznie działających spółdzielni socjalnych. Według opinii części ekspertów działalność prowadzi ok. 1/3 z nich [Spółdzielczość, 2011, s. 3].

Tabela 1. Liczba zarejestrowanych spółdzielni socjalnych

\begin{tabular}{|c|c|}
\hline Rok & $\begin{array}{c}\text { Lizzba zarejestrowanych } \\
\text { spółdzielni socjalnych łącznie }\end{array}$ \\
\hline 2009 & 187 \\
\hline 2010 & 276 \\
\hline 2011 & 402 \\
\hline 2012 & 615 \\
\hline 2013 & 936 \\
\hline $2015^{*}$ & 1381 \\
\hline
\end{tabular}

* według Krajowego Rejestru Sądowego, stan na 31 grudnia $2015 \mathrm{r}$.

Źródło: [Informacja, 2015].

Przedsiębiorstwami społecznymi mogą być również organizacje pozarządowe i inne podmioty działające w sferze pożytku publicznego, prowadzące działalność gospodarczą. Według danych GUS w 2012 r. działało ich 
Tabela 2. Liczba zarejestrowanych spółdzielni według rodzajów działalności

\begin{tabular}{|l|c|}
\hline \multicolumn{1}{|c|}{ Podział działalności według PKD 2007 } & $\begin{array}{c}\text { Liczba } \\
\text { zarejestrowanych } \\
\text { spółdzielni }\end{array}$ \\
\hline Sekcja A - Rolnictwo, leśnictwo, łowiectwo i rybactwo & 2645 \\
\hline $\begin{array}{l}\text { Sekcja B - Górnictwo i wydobywanie, Sekcja C - Przetwórstwo przemysłowe, Sekcja D - wytwarzanie i } \\
\text { zaopatrywanie w energię elektryczną, gaz, parę wodną, gorącą wodę i powietrze do układów klimatyzacyjnych, } \\
\text { Sekcja E - dostawa wody; gospodarowanie ściekami i odpadami oraz działalność związana z rekultywacją }\end{array}$ & 1718 \\
\hline Sekcja F - Budownictwo & 2218 \\
\hline Sekcja G - Handel hurtowy i detaliczny; naprawa pojazdów samochodowych, włączając motocykle & 3005 \\
\hline Sekcja L - Działalność związana z obsługą rynku nieruchomości & 5408 \\
\hline Ogółem: & 17605 \\
\hline
\end{tabular}

Źródło: [GUS-BDL].

(w tym również podmiotów wyznaniowych) 83,5 tys., z tego 7\%, czyli 5,8 tys. prowadziło działalność gospodarczą [Wstępne wyniki..., 2014 , s. 2]. Nie wszystkie z nich oczywiście spełniają pozostałe kryteria przedsiębiorstwa społecznego, na przykład kryterium zatrudnienia. Również o ile w przypadku stowarzyszeń można przyjąć, że ich ustawowa konstrukcja pozwala spełnić wymóg zarządzania na zasadach demokratycznych, o tyle prawo nie wymusza takich rozwiązań w przypadku fundacji czy organizacji wyznaniowych, co nie oznacza, że nie mogą one same ich wprowadzać. Dla ogólnej liczby organizacji przychody z działalności gospodarczej stanowiły ok. 18\% ogółu przychodów w 2012 r. [ibidem, s. 6, 9, 15].

Trzecia grupa przedsiębiorstw społecznych rekrutuje się z tak zwanych spółek non-profit. Nie jest to odrębna forma prawna, ale zgodnie z kodeksem spółek handlowych, spółka może działać w każdym dopuszczalnym prawem celu, w tym także społecznym. Spółka non-profit, takie określenie przyjęte zostało potocznie, oznacza spółkę, w której - zgodnie z aktem założycielskim - zyski z działalności gospodarczej nie są dzielone między udziałowców, a przeznaczane na cele społecznie użyteczne [Kozioł]. Są to z reguły spółki z ograniczoną odpowiedzialnością. Trudno dokładnie określić ich liczbę z uwagi na brak wyróżnienia tej formy w prawie. Szacunkowe dane mówią o ok. 30 takich podmiotach działających w Polsce [Krajowy Program..., 2014]. Są to najczęściej spółki tworzone jako przedsiębiorstwa społeczne, na przykład Biłgorajskie Przedsiębiorstwo Społeczne czy Diakonijna Spółka Zatrudnienia.

Ostatnia grupa przedsiębiorstw społecznych to spółdzielnie. Według GUS w 2014 r. zarejestrowanych było ponad 17,5 tysiąca spółdzielni (w tym także socjalnych).

Z danych GUS wynika, że najliczniejszą grupę stanowią spółdzielnie zarejestrowane w sekcji L czyli przede wszystkim spółdzielnie mieszkaniowe, które jednak z reguły nie spełniają kryteriów przedsiębiorstwa społecznego (tabela 2). Najczęściej te kryteria mogą spełniać spółdzielnie, których celem jest zatrudnienie. Są to: spółdzielnie pracy, spółdzielnie inwalidów i niewidomych, spółdzielnia rękodzieła ludowego "Cepelia” oraz wspomniane wcześniej spółdzielnie socjalne. Według danych z 2012 r. czynnych spółdzielni pracy w Polsce było 648, spółdzielni inwalidów i niewidomych - 224, a spółdzielni rękodzieła ludowego - 9, co daje łączną liczbę 881 czynnych podmiotów gospodarczych. Największa część spółdzielni pracy zrzeszona jest w Związku Lustracyjnym Spółdzielni Pracy (ponad 200 podmiotów), natomiast 
drugim co do wielkości zrzeszeniem w tej branży jest Spółdzielczy Związek Rewizyjny „Wspólnota Pracy", który zrzesza 84 spółdzielnie. W związku rewizyjnym "Cepelia" zrzeszonych jest 18 spółdzielni. Związek Rzemiosła Polskiego podaje, że w jego strukturach oraz strukturach izb rzemieślniczych działa 168 spółdzielni [Krajowy Program..., 2014].

Podsumowując można powiedzieć, że przedsiębiorstwa społeczne w Polsce to co najmniej 450 działających spółdzielni socjalnych oraz od 1.000 do 2.000 spółdzielni pracy, stowarzyszeń, fundacji, spółek z ograniczoną odpowiedzialną, organizacji wyznaniowych i zakładów aktywności zawodowej spełniających kryteria przedsiębiorstwa społecznego.

\section{Główne źródła finansowania działalności przedsiębiorstw społecznych}

Działalność przedsiębiorstw społecznych może być finansowana z różnych źródeł (tabela 3).Zzałożenia podstawowym źródłem finansowania przedsiębiorstwa społecznego powinna być prowadzona przez nie działalność gospodarcza, polegająca przede wszystkim na sprzedaży usług oraz produktów. Trzeba pamiętać jednak o ograniczeniach prawnych w tym zakresie. O ile spółdzielnie (w tym spółdzielnie socjalne) oraz spółki non-profit mogą prowadzić działalność gospodarczą bez żadnych ograniczeń, o tyle w przypadku organizacji pozarządowych, zgodnie z przyjętą doktryną, działalność gospodarcza powinna być uzupełnieniem, mieć dodatkowy charakter wobec działalności statutowej [Ignaszczak, 2012 , s. 2]. Prawo nie precyzuje tego dodatkowego charakteru, ale można przyjąć, że oznacza to, iż przychody z działalności gospodarczej nie dominują w łącznych przychodach organizacji.

Za oddzielne źródło finansowania, choć wykorzystywane w ramach działalności gospodarczej (lub statutowej odpłatnej), nale- ży uznać zamówienia publiczne, czyli zlecanie przedsiębiorstwom społecznym realizacji zadań publicznych w oparciu o Prawo zamówień publicznych. Jest to spory rynek: wartość zamówień publicznych udzielanych na podstawie przepisów Prawa zamówień publicznych wyniosła w 2014 r. 133,2 mld złotych, a największą grupę zamawiających stanowiły samorządy terytorialne (68,9\%) [Sprawozdanie, 2015, s. 29-30].

Kolejnym źródłem finansowania w ramach działalności gospodarczej są dotacje przyznawane w ramach programów operacyjnych finansowanych ze środków unijnych. Pozyskiwane są w drodze konkursu, w którym z reguły mogą brać udział różne podmioty prowadzące działalność gospodarczą. Działalność gospodarcza może być również finansowana z pozyskanych przez przedsiębiorstwa pożyczek i kredytów, czyli instrumentów zwrotnych.

Przedsiębiorstwa społeczne mogą także realizować zadania publiczne $w$ ramach działalności pożytku publicznego. Zadania te zlecane są najczęściej w trybie otwartego konkursu ofert, zgodnie z ustawą o działalności pożytku publicznego i o wolontariacie. Dotacje na zadania realizowane w ramach działalności pożytku publicznego mogą być także przyznawane w konkursach w ramach programów operacyjnych finansowanych ze środków unijnych. W ramach działalności pożytku publicznego organizacje pozarządowe mogą prowadzić działalność odpłatną, ale przychody z niej zgodnie z prawem mogą służyć jedynie pokrywaniu kosztów związanych z tą działalnością. Na działalność pożytku publicznego mogą być pozyskiwane również dotacje z prywatnych źródeł finansowania (firm i organizacji pozarządowych), a także darowizny od osób prawnych i fizycznych. W przypadku podmiotów posiadających status organizacji pożytku publicznego źródłem finansowania działalności pożytku publicznego mogą być także wpływy z odpisu $1 \%$ podatku dochodowego od osób fizycz- 
Tabela 3. Główne źródła finansowania działalności przedsiębiorstw społecznych

\begin{tabular}{|l|l|}
\hline Działalność gospodarcza & Działalność pożytku publicznego \\
\hline -Sprzedaż usług, towarów & - Dotacje na realizację zadań publicznych ze środków krajowych \\
-Zamówienia publiczne & i unijnych \\
- Dotacje na zadania publiczne realizowane w ramach & - Dotacje ze źródeł prywatnych \\
działalności gospodarczej ze środków krajowych i unijnych & - Darowizny od osób fizycznych i prawnych \\
- Pożyczki, kredyty & - Odpłatna działalnó́ć statutowa \\
- Udziałły (spółdzielnie, spółki) & - Składki członkowskie (stowarzyszenia) \\
- Dotacje na założenie spółdzielni socjalnej (FP, PFRON, EFS) & $-1 \%$ PIT (organizacje pożytku publicznego) \\
& - Zbiórki publiczne \\
\hline
\end{tabular}

Źródło: opracowanie własne.

nych. Należy zauważyć, że dotacje, darowizny czy też odpis 1\% mogą być przeznaczone wyłącznie na działalność pożytku publicznego. Na działalność pożytku publicznego można także pozyskiwać środki w ramach zbiórek publicznych.

Niektóre źródła finansowania przedsiębiorstw społecznych są ściśle powiązane z określonymi prawnymi formami ich działania. Stowarzyszenia mogą na przykład finansować działalność ze składek członkowskich, spółki z udziałów, a spółdzielnie z udziałów i wkładów członkowskich. Dostępne są także dodatkowe możliwości wsparcia finansowego, dotyczące jednak wyłącznie spółdzielni socjalnych. Osoby chcące założyć spółdzielnię socjalną mogą otrzymać jednorazowo środki z Funduszu Pracy na podjęcie działalności gospodarczej w wysokości nieprzekraczającej czterokrotnej wysokości przeciętnego wynagrodzenia na każdego członka założyciela spółdzielni socjalnej. Z kolei osoby chcące przystąpić do już istniejącej spółdzielni socjalnej mogą otrzymać środki z Funduszu Pracy w wysokości 3-krotności przeciętnego wynagrodzenia na każdego członka. Spółdzielnia socjalna ma możliwość ubiegania się o sfinansowanie ze środków Funduszu Pracy części wynagrodzenia odpowiadającej składce należnej od zatrudnionego na ubezpieczenia emerytalne, rentowe i chorobowe oraz części kosztów osobowych pracodawcy odpowiadającej składce na ubezpieczenia emerytalne, rentowe i wypadkowe. Finansowanie odbywa się na podstawie umowy zawartej między starostą właściwym ze względu na siedzibę spółdzielni socjalnej, a spółdzielnią socjalną i dotyczy osób zagrożonych wykluczeniem społecznym. Finansowanie może być dokonywane w pełnej wysokości przez okres 24 miesięcy od dnia zatrudnienia oraz w połowie wysokości przez kolejne 12 miesięcy. Zwroty składek ubezpieczeniowych dokonywane są w okresach kwartalnych. Od 2009 r. spółdzielnie socjalne mają również możliwość ubiegania się o miesięczne zaliczki na opłacanie składek ubezpieczenia społecznego. Tworzenie spółdzielni socjalnych zostało również wsparte pośrednio poprzez finansowanie w ramach Programu Operacyjnego Kapitał Ludzki działalności ośrodków wsparcia ekonomii społecznej, które doradczo, szkoleniowo, a także finansowo wspierały zakładanie spółdzielni socjalnych.

\section{Finansowanie przedsiębiorstw społecznych w praktyce}

Nie istnieją spójne i kompleksowe dane dotyczące wykorzystywania opisanych wyżej źródeł finansowania w praktyce. Można jedynie pokazać fragmentaryczny obraz finansowania przedsiębiorstw społecznych, przede wszystkim poprzez wyniki badań regionalnych dotyczących podmiotów ekonomii społecznej oraz monitoringu działalności spółdzielni socjalnych prowadzonego przez Ministerstwo Pracy i Polityki Społecznej (obecnie: Ministerstwo 


\section{Rysunek 2. Udział poszczególnych źródeł finansowania w ogólnej puli środków zaplanowanych na realizację KPRES (w \%)}

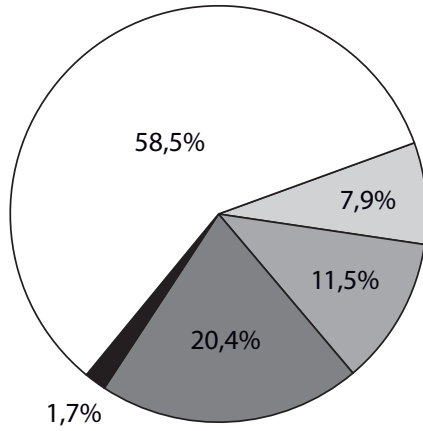

Źródło: opracowanie własne na podstawie KPRES samorządy terytorialne

państwo

państwowe fudnusze celowe

krajowe środki prywatne

środki z UE
Rodziny, Pracy i Polityki Społecznej). Badania przeprowadzone w różnych okresach w kilku regionach pokazują wyraźnie pewne wspólne tendencje dotyczące finansowania. Nie są to dane precyzyjnie obrazujące finansowanie przedsiębiorstw społecznych, bo dotyczą w części szerszej kategorii podmiotów ekonomii społecznej, ale wśród nich istotną grupę stanowią przedsiębiorstwa społeczne.

Przedsiębiorczość społeczna w Polsce w ostatnich kilkunastu latach rozwija się w dużej mierze dzięki wsparciu ze środków publicznych, głównie europejskich. Począwszy od środków Europejskiego Funduszu Społecznego w ramach wspomnianej na początku artykułu IW EQUAL (2005-2008), przez program Ministra Pracy i Polityki Społecznej „Wspieranie rozwoju spółdzielczości socjalnej", Program Operacyjny Kapitał Ludzki, kończąc na nowej perspektywie finansowej na lata 2014-2020, w której także przewidziano środki służące rozwojowi przedsiębiorczości społecznej. W Krajowym Programie Rozwoju Przedsiębiorczości Społecznej na realizację różnego rodzaju działań przewidziano w latach 2014-2020 łącznie 2,74 miliarda złotych, z czego ponad połowę stanowić mają środki unijne (rysunek 2).

Działalność gospodarcza, istotna zwłaszcza w przypadku spółdzielni czy spółek, rzad- ko bywa jedynym źródłem finansowania działalności przedsiębiorstw społecznych, a dość często jest jedynie źródłem dodatkowym. $\mathrm{Na}$ przykład w województwie kujawsko-pomorskim w 2011 r. żaden podmiot ekonomii społecznej nie finansował się w całości z przychodów z działalności gospodarczej, a główne źródła finansowania tych podmiotów stanowiły źródła publiczne [Raport, 2011, s. 66]. Środki publiczne były również dominującym źródłem finansowania podmiotów ekonomii społecznej, w tym przedsiębiorstw społecznych, w województwie opolskim w 2014 r. [Potencjał, 2014, s. 12]. Okazało się także, że podmioty ekonomii społecznej w tym województwie nie korzystały i nie zamierzały w większości korzystać ze zwrotnych instrumentów finansowania (pożyczki, kredyty) [ibidem, s. 16-17].

Z przeprowadzonych badań wynika przede wszystkim dość słaba kondycja finansowa podmiotów ekonomii społecznej, w tym przedsiębiorstw społecznych. Stąd też jednym z najczęściej wskazywanych przez badane podmioty problemów jest pozyskiwanie funduszy na działalność [Badanie podmiotów..., 2015, s. 64; Raport, 2011, s. 66]. Badanie spółdzielni socjalnych w województwie łódzkim wykazało, że prawie $70 \%$ spółdzielni ma problemy z finansowaniem działalności. Okazało 
się również, że ponad $90 \%$ spółdzielni socjalnych nie powstałaby bez dofinansowania ze środków europejskich [Lis, Wojtkowiak, 2013, s. 4]. Potwierdzają to wyniki badania spółdzielni socjalnych w województwie podlaskim, gdzie większość z nich powstała dzięki wsparciu Europejskiego Funduszu Społecznego. Ponad 60\% badanych podlaskich spółdzielni socjalnych ocenia swoją kondycję finansową jako średnią, jako dobrą oceniło ją 20\%, a jako złą lub bardzo złą odpowiednio $6 \%$ i 7\% badanych spółdzielni. Żadna ze spółdzielni nie oceniła swojej kondycji finansowej jako bardzo dobrej [Diagnoza, 2013, s. 30].

W województwie małopolskim w 2013 r. zysk z prowadzenia działalności ekonomicznej wykazało ok. $40 \%$ podmiotów ekonomii społecznej, a co piąty wykazał stratę, przy czym sytuacja w tym zakresie pogorszyła się w porównaniu z rokiem poprzednim [Monitoring, 2013, s. 10-11]. W województwie lubelskim w 2012 r. średni roczny przychód spółdzielni socjalnych wyniósł nieco ponad 77 tys. zł, z czego przychód z tytułu sprzedaży dóbr i usług wyniósł niespełna 50 tys. zł [Badanie kondycji..., 2013, s. 38]. Podobnie wśród małopolskich podmiotów ekonomii społecznej w 2012 r. było zaledwie 7\% takich, które opierały swoją działalność na przychodach z działalności gospodarczej. Najczęściej (43\%) podmioty ekonomii społecznej wykazywały środki publiczne jako główne źródło finansowania [Lombardzkie, 2012, s. 22].

Nieco więcej wiemy na temat spółdzielni socjalnych, dzięki monitoringowi prowadzonemu przez Ministerstwo Pracy i Polityki Społecznej. Dane zebrane przez Ministerstwo za lata 2012-2013 nie są jednak reprezentatywne, ponieważ dotyczą jedynie 144 spółdzielni, co stanowiło 15,4\% wszystkich zarejestrowanych na koniec 2013 r. spółdzielni socjalnych [Informacja, 2015, s. 38]. Najczęściej wskazywanymi przez przebadane spółdzielnie socjalne źródłami finansowania działalności w latach 2012-2013 były zyski z prowadzonej przez spółdzielnie socjalne działalności gospodarczej oraz środki uzyskane z Programu Operacyjnego Kapitał Ludzki. Te odpowiedzi wskazało odpowiednio 74,2\% oraz 44\% spółdzielni socjalnych biorących udział w badaniu. Jedna piąta spółdzielni socjalnych deklarowała uzyskanie środków z Funduszu Pracy lub Państwowego Funduszu Rehabilitacji Osób Niepełnosprawnych [ibidem, s. 74].

Przychody większości badanych spółdzielni socjalnych w 2013 roku nie przekroczyły rocznie 100 tysięcy złotych:

\section{Tabela 3. Struktura spółdzielni socjalnych według kwoty całkowitego przychodu w latach 2012-2013}

\begin{tabular}{|l|c|c|}
\hline \multicolumn{1}{|c|}{$\begin{array}{c}\text { Przedziały kwotowe } \\
\text { w tys. zł }\end{array}$} & \multicolumn{2}{c|}{$\begin{array}{c}\text { \% spółdzielni socjalnych } \\
\text { mieszzzących się w danym } \\
\text { przedziale w: }\end{array}$} \\
\cline { 2 - 3 } & 2012 r. & 2013 r. \\
\hline brak przychodu lub strata & $8,7 \%$ & $13,6 \%$ \\
\hline 1 zł - do 10 tys. & $13 \%$ & $13,6 \%$ \\
\hline powyżej 10 tys. - do 50 tys. & $18,8 \%$ & $17,4 \%$ \\
\hline powyżej 50 tys. - do 100 tys. & $17,4 \%$ & $19,7 \%$ \\
\hline powyżej 100 tys. - do 200 tys. & $11,7 \%$ & $15,1 \%$ \\
\hline powyżej 200 tys. - do 300 tys. & $4,3 \%$ & $7,5 \%$ \\
\hline powyżej 300 tys. - do 500 tys. & $7,2 \%$ & $6,8 \%$ \\
\hline powyżej 500 tys.- do $1 \mathrm{mln}$ & $1,4 \%$ & $3 \%$ \\
\hline powyżej $1 \mathrm{mln}$ & $7,2 \%$ & $3 \%$ \\
\hline
\end{tabular}

Źródło: [Informacja, 2015, s. 78].

Badane spółdzielnie socjalne pytane były również o niezależność finansową. Jedynie 18,2\% spółdzielni socjalnych wyraziła przekonanie, iż są w dużej mierze lub całkowicie niezależne pod względem finansowym. Ponad trzy czwarte spółdzielni socjalnych $(78,8 \%)$ uważa, że finansowe wsparcie zewnętrzne jest wskazane lub wręcz niezbędne dla ich dalszego funkcjonowania [ibidem, s. 82].

Przeprowadzony przez resort pracy monitoring dostarczył także informacji dotyczących wykorzystania przez spółdzielnie socjalne możliwości finansowania ich działalności adresowanych wyłącznie dla nich. W latach 
2009-2013 przyznano ze środków Funduszu Pracy dotacje na podjęcie działalności w formie spółdzielni socjalnej 586 osobom na łączną kwotę prawie 7 milionów złotych [ibidem, s. 10]. W 2013 r. wydatki z Funduszu Pracy na zwrot opłaconych przez spółdzielnie socjalne wydatków obejmujących część wynagrodzenia oraz kosztów osobowych pracodawcy odpowiadających składce na ubezpieczenia społeczne łącznie wyniosły 865,8 tys. zł [ibidem, s. 15]. Z kolei w latach 2010-2013 z Państwowego Funduszu Rehabilitacji Osób Niepełnosprawnych środki na wniesienie wkładu do spółdzielni socjalnej otrzymało 97 osób na łączną kwotę ponad 2,5 mln zł. Dzięki wsparciu EFS utworzono 343 spółdzielnie socjalne do końca 2013 r. [ibidem, s. 17-18].

W przypadku przedsiębiorstw społecznych działających w formie stowarzyszeń, fundacji lub organizacji wyznaniowych, istotnym źródłem finansowania są darowizny od osób fizycznych i prawnych oraz dotacje na realizację zadań publicznych. Dotacje przyznawane są przede wszystkim przez samorządy terytorialne oraz Program Operacyjny Fundusz Inicjatyw Obywatelskich, z którego korzystają również spółdzielnie socjalne. Dotacje na realizację projektów w ramach środków europejskich wydają się być raczej marginesem $\mathrm{w}$ finansowaniu przedsiębiorstw społecznych. Na przykład na ponad 47,7 tysiąca umów na realizację projektów zawartych w ramach Programu Operacyjnego Kapitał Ludzki spółdzielnie (w tym socjalne) zawarły jedynie ok. 60 umów [Lista, 2015].

Źródłem finansowania działalności przedsiębiorstw społecznych są również instrumenty zwrotne (pożyczki i kredyty). Jednak oferta kredytów i pożyczek adresowanych do podmiotów ekonomii społecznej była dotychczas niewielka, a podmioty ekonomii społecznej nie miały doświadczeń w korzystaniu z nich. Barierą jest też niska jakość zarządzania finansami w podmiotach ekonomii społecznej, która zwiększa ryzyko i związane z nim obawy spłacenia pożyczki czy kredytu [Schimanek, Wolińska, 2011, s. 23]. Pożyczek dla podmiotów ekonomii społecznej i innych organizacji pozarządowych udziela Fundusz PAFPIO, który od 1999 r. przyznał 1.986 pożyczek 571 organizacjom [PAFPIO] oraz Towarzystwo Inicjatyw Społeczno-Ekonomicznych (TISE). TISE jest także operatorem funduszu mikropożyczek dla podmiotów ekonomii społecznej finansowanego z Europejskiego Funduszu Społecznego. W ramach tego funduszu wypłacone zostały 382 pożyczki dla 311 podmiotów na łączną kwotę 30 milionów złotych [ES Fundusz]. Pojedynczych pożyczek podmiotom ekonomii społecznej udzielają również fundusze pożyczkowe dla małych i średnich przedsiębiorstw, prywatne fundusze pożyczkowe, a kredytów banki, głównie spółdzielcze.

\section{Wyzwania}

Wydaje się, że obecną sytuację finansowania przedsiębiorstw społecznych można poprawić przede wszystkim porządkując kwestie prawne dotyczące działalności i finansowania przedsiębiorstw społecznych, tworząc możliwości dla rozwoju działalności gospodarczej i inwestowania w nią, a także wzmacniając wiedzę biznesową osób zarządzających przedsiębiorstwami społecznymi.

W Krajowym Programie Rozwoju Ekonomii Społecznej znajdują się propozycje w dużej mierze odpowiadające na te potrzeby związane z finansowaniem przedsiębiorstw społecznych. Począwszy od zapowiedzi przyjęcia ustawy o przedsiębiorstwie społecznym i wspieraniu ekonomii społecznej, poprzez wprowadzenie w przepisach Prawa zamówień publicznych zmian wynikających z nowych dyrektyw unijnych w zakresie zamówień publicznych, wprowadzenie możliwości wsparcia inwestycyjnego przedsiębiorstw społecznych, zwiększenia roli wsparcia w zakresie prowadzonej działalności gospodarczej, kończąc na powszechnym systemie pożyczek i poręczeń [Krajowy Program... 2014]. Najważniejszym 
obecnie wyzwaniem wydaje się przełożenie tych ogólnych zapisów KPRES na działania operacyjne i ich konsekwentna realizacja.

Z pewnością także, aby skutecznie adresować wsparcie dla przedsiębiorstw społecznych, potrzebna jest rzetelna wiedza na temat przedsiębiorstw społecznych i innych podmiotów ekonomii społecznej, również o ich kondycji finansowej. W tym celu, z jednej strony, niezbędne jest zebranie i przeanalizowanie dotychczasowych danych dotyczących przedsiębiorczości społecznej w Polsce, z drugiej zaś - uruchomienie stałego, spójnego i kompleksowego monitoringu ekonomii społecznej, opartego na statystyce publicznej a także badaniach prowadzonych przez podmioty odpowiedzialne za wdrażanie KPRES. Taki monitoring został przewidziany w Krajowym Programie Rozwoju Ekonomii Społecznej, warto zadbać o to, aby znalazły się środki na jego rzetelną i ciągłą realizację. W ramach monitoringu trzeba zastosować przyjęte w KPRES definicje ekonomii społecznej i przedsiębiorstw społecznych.

Najtrudniejszym wyzwaniem w realizacji Krajowego Programu Rozwoju Ekonomii Społecznej, a jednocześnie największym potencjalnym zagrożeniem dla przedsiębiorczości społecznej, jest takie sprofilowanie wsparcia publicznego, aby przyczyniało się ono do budowania samodzielności finansowej przedsiębiorstw społecznych w Polsce, a nie powodowało dalszego uzależnienie od środków publicznych.

\section{Podsumowanie}

Z analizy, co prawda fragmentarycznych i niepełnych, danych wyłania się jednak relatywnie jednoznaczny obraz finansowania i kondycji finansowej przedsiębiorstw społecznych. Najważniejsze wnioski z przeprowadzonej analizy dotyczące finansowania przedsiębiorstw społecznych można przedstawić w kilku najważniejszych punktach:

1. Sytuacja finansowa większości przedsiębiorstw społecznych jest nienajlepsza, pozwala im jedynie utrzymać działalność na minimalnym poziomie, dość często z ujemnym wynikiem finansowym. Wynika to z niewielkich przychodów większości przedsiębiorstw społecznych oraz ze zbyt małego ich udziału w działalności gospodarczej. Ten drugi czynnik powoduje, że przedsiębiorstwa społeczne nie mogą inwestować w rozwój, co mogłoby dawać w przyszłości większe przychody. Zyski z działalności gospodarczej są bowiem - oprócz pożyczek czy kredytów - w praktyce jedyną możliwością finansowania inwestycji. Środki publiczne, czy też dotacje lub darowizny najczęściej są przeznaczone na działalność pożytku publicznego, a jeżeli można je wykorzystać w działalności gospodarczej, to z reguły na pokrycie konkretnych kosztów operacyjnych prowadzonej działalności gospodarczej, a nie na nią samą.

2. Mówiąc o działalności gospodarczej warto zwrócić uwagę na zamówienia publiczne i dotacje na realizację zadań publicznych finansowanych ze środków unijnych. Co prawda brakuje kompleksowych danych, ale te fragmentaryczne, które są dostępne, wydają się wskazywać, że przedsiębiorstwa społeczne korzystają z tych możliwości w ograniczonym zakresie. Wynika to przede wszystkim z braku wiedzy i doświadczeń w zakresie korzystania z zamówień publicznych, a także często mniejszej konkurencyjności cenowej przedsiębiorstw społecznych w porównaniu z podmiotami czysto komercyjnymi.

3. Wszystkie badania potwierdzają istotny udział środków publicznych w finansowaniu działalności przedsiębiorstw społecznych. W szczególności dotyczy to spółdzielni socjalnych, które mogą korzystać w tym zakresie z możliwości niedostępnych dla innych przedsiębiorstw społecznych. Wydaje się mieć to dwie istotne konsekwencje. Po pierwsze, co widać wyraźnie w badaniach, zmniejsza to niezależność 
(nie tylko finansową) przedsiębiorstw społecznych. Po drugie, dostęp do środków publicznych wydaje się powodować mniejsze zainteresowanie części korzystających z nich przedsiębiorstw społecznych rozwijaniem działalności gospodarczej. Wiąże się to także z brakiem wiedzy i doświadczeń w prowadzeniu własnej firmy oraz zwłaszcza w przypadku organizacji pozarządowych - z mentalnymi trudnościami w przyjęciu biznesowego sposobu funkcjonowania [Turek, Sobczyk-Turek, 2013, s. 3]. To z kolei przyczynia się do niskiej rentowności działalności gospodarczej przedsiębiorstw społecznych, na co wpływ ma także dokonywanie wyboru przedmiotu tej działalności nie na podstawie analiz rynku, ale na podstawie możliwości członków/ pracowników przedsiębiorstwa społecznego [ibidem, s. 11].

4. W marginalnym zakresie przedsiębiorstwa korzystają z instrumentów zwrotnych, a to

\section{Literatura}

Badanie kondycji podmiotów ekonomii społecznej: spółdzielni socjalnych, spółek non-profit, centrów integracji społecznej, klubów integracji społecznej funkcjonujących na terenie województwa lubelskiego. Raport końcowy (2013). Lublin: Regionalny Ośrodek Polityki Społecznej w Lublinie.

Badanie podmiotów ekonomii społecznej w subregionie południowym województwa śląskiego (2015). Bielsko-Biała: Stowarzyszenie Bielskie Centrum Przedsiębiorczości.

Defourny J., Nyssens M. (2012). The EMES approach of social enterprise in a comparative perspective, WP no. 12/03, EMES European Research Network.

Diagnoza stanu i potrzeb spółdzielni socjalnych z terenu województwa podlaskiego (2013). Białystok: Regionalny Ośrodek Polityki Społecznej w Białymstoku, Obserwatorium Integracji Społecznej.

ES Fundusz - strona internetowa ES Funduszu: http://esfundusz.pl.

Frączek M., Hausner J., Mazur S. (red.) (2012). Wokót ekonomii społecznej. Kraków: Małopolska Szkoła Administracji Publicznej UEK.

Grewiński M. (2012). „Gospodarka społeczna W UE i w Polsce - między przedsiębiorczością społeczną mógłby być sposób na rozwinięcie działalności gospodarczej, w szczególności na niezbędne $w$ tym celu inwestycje. Z pewnością krokiem służącym upowszechnieniu wśród przedsiębiorstw społecznych pożyczek jest realizowany obecnie program mikropożyczek finansowanych z Europejskiego Funduszu Społecznego i planowana jego kontynuacja - w większej skali - w ramach Programu Operacyjnego Wiedza Edukacja Rozwój.

5. Z przeprowadzonych badań widać także wyraźne uprzywilejowanie spółdzielni socjalnych w porównaniu z przedsiębiorstwami społecznymi działającymi w innych formach prawnych. Nie przyczynia się to do zrównoważonego rozwoju przedsiębiorczości społecznej i zniechęca stowarzyszenia, fundacje czy spółdzielnie nie będące socjalnymi do przekształcania się w przedsiębiorstwa społeczne.

i CSR", w: Przedsiębiorczość - stan i perspektywy. Warszawa: WSP TWP.

GUS-BDL (2014). Bank Danych Lokalnych GUS za 2014 rok.

Hausner J. (2008). Przedsiębiorstwa społeczne w Polsce. Teoria i praktyka. Kraków: Małopolska Szkoła Administracji Publicznej UEK.

Herbst K. (2013). „Perspektywy ekonomii społecznej”, Ekonomia Spoleczna, nr 1(6)

Ignaszczak S. (2012). „Aspekty prawne działalności gospodarczej organizacji pozarządowych", LOS. Pismo Samopomocy Społecznej, nr 95.

Informacja o funkcjonowaniu spółdzielni socjalnych działających na podstawie ustawy z dnia 27 kwietnia 2006 r. o spółdzielniach socjalnych za okres 2012-2013 (2015). Warszawa: Ministerstwo Pracy i Polityki Społecznej.

Kaźmierczak T. (2007). „Zrozumieć ekonomię społeczną", w: T. Kaźmierczak, M. Rymsza (red), Kapitał społeczny. Ekonomia Społeczna. Warszawa: Instytut Spraw Publicznych.

Kozioł K., Spółka kapitałowa może działać non-profit, wWw.cxo.pl.

Krajowy Program Rozwoju Ekonomii Społecznej (2014). Warszawa: Ministerstwo Pracy i Polityki Społecznej. 
Lech K. (2012). „Przedsiębiorczość społeczna. Prolegomena: termin i definicje zjawiska", Zarzadzanie zmianami. Zeszyty Naukowe Wyższej Szkoły Zarządzania/Polish Open University, nr 3-4 (57).

Lis M., Wojtkowiak M. (2013). Ocena wpływu interwencji Europejskiego Funduszu Społecznego podejmowanych w ramach Priorytetu VII PO KL na problem wykluczenia społecznego w województwie łódzkim. Doradztwo Społeczne i Gospodarcze.

Lista beneficjentów Programu Operacyjnego Kapitał Ludzki, KSI SIMIK 07-13 - stan na 1 czerwca 2015 r.

Lombardzkie mechanizmy finansowe wspierające ekonomię społeczną. Rekomendacje dla Małopolski (2012), Kraków: Regionalny Ośrodek Polityki Społecznej w Krakowie.

Monitoring sektora ekonomii społecznej - Raport (2013). Poznań: Regionalny Ośrodek Polityki Społecznej w Poznaniu.

PAFPIO, strona internetowa http://pafpio.pl.

Potencjał wykorzystania instrumentów inżynierii finansowej przez podmioty ekonomii społecznej w województwie opolskim (2014). Opole: Regionalny Ośrodek Polityki Społecznej w Opolu, Obserwatorium Integracji Społecznej.

Proposal for a Regulation of the European Parliament and of the Council on European Social Entrepreneurship Funds (2011). Brussels, COD 2011/0418.

Raport z kompleksowego badania sektora ekonomii społecznej w regionie kujawsko-pomorskim w ramach projektu systemowego ROPS w Toruniu pn."Akademia Pomocy i Integracji Społecznej - Wsparcie kadr" (2011). Toruń: PBS.
Schimanek T. (2011). Uzasadnienie do projektu ustawy o przedsiębiorczości społecznej i przedsiębiorstwie społecznym, opracowanie niepublikowane, dostępne na portalu: www.ekonomiaspoleczna.pl.

Schimanek T. (2013). "Bilans czterech lat kształtowania prawa ekonomii społecznej w Polsce", w: T. Schimanek, M. Gałązka, F. Pazderski, D. Potkańska, I. Przybysz, Podsumowanie monitoringu prawa przedsiębiorczości społecznej, Warszawa: Instytut Spraw Publicznych.

Schimanek T., Wolińska M. (2011). Raport podsumowujący badanie możliwości stworzenia Instrumentu Finansowego dla organizacji pozarząowych i instytucji ekonomii społecznej, Warszawa: WYG International.

Sienicka A. (2009). "Geneza oraz krajowy i zagraniczny kontekst przedsiębiorczości społecznej”, w: T. Schimanek (red.), Przedsiębiorstwo społeczne w działaniu. Warszawa: WYG International.

Spółdzielczość socjalna w Polsce (2011). Warszawa: Biuro Rzecznika Praw Obywatelskich.

Sprawozdanie Prezesa Urzędu Zamówień Publicznych o funkcjonowaniu systemu zamówień publicznych w 2014 r. (2015). Warszawa: Urząd Zamówień Publicznych,

Turek K., Sobczyk-Turek A. (2013). Bariery w prowadzeniu działalności ekonomicznej przez podmioty ekonomii społecznej. Fundacja Biuro Inicjatyw Społecznych.

Wstępne wyniki badania społecznej i ekonomicznej kondycji organizacji trzeciego sektora w 2012 r. (2014). Warszawa: Główny Urząd Statystyczny.

\section{Financing of social enterprises in Poland}

Summary: The article discusses various approaches to defining social enterprise in Poland. The potential sources of funding of social enterprises are indicated and their use in practice is described. An analysis of available data shows that most social enterprises have very low incomes that are sufficient only to finance current activity. A few social enterprises are financed out of business, most of them use public funds, and they do not have the possibility of financing development, especially investments. The situation may be improved through consistent implementation of activities planned in the National Programme for the Development of Social Economy, but public funds must be used in such way as to strengthen the independence and financial sustainability of social enterprises.

Keywords: social enterprise, financing, The National Programme for the Development of Social Economy.

\section{Prawa autorskie i licencja / Copyright and License}

Artykuł opublikowano na licencji Creative Commons

Uznanie autorstwa - Użycie niekomercyjne - Bez utworów zależnych 3.0 Polska http://creativecommons.org/licenses/by-nc-nd/3.0/pl/

This article is published under the terms of the Creative Commons

Attribution - NonCommercial - NoDerivs (CC BY-NC-ND 3.0) License

http://creativecommons.org/licenses/by-nc-nd/3.0/ 